\title{
The Reflection of the Ethnic Ethos in the Shaping of Mizrahi Female Characters, in the Light of the Literary Criticism of Yaakov Churgin's Books - Sipurim (1928), Alumot (1957), and Yalkut Sipurim (1981)
}

\author{
Nitsa Dori ${ }^{1}$ \\ ${ }^{1}$ Head of the Department of Early Childhood, Shaanan Academic College, Haifa, Israel \\ Correspondence: Nitsa Dori, 8 Eliyahu HaGiladi St., Netanya, Israel. \\ Received: December 5, 2019 \\ Accepted: December 20, 2019 \\ Available online: January 21, 2020 \\ doi:10.11114/ijsss.v8i2.4694 \\ URL: https://doi.org/10.11114/ijsss.v8i2.4694
}

\begin{abstract}
This article suggests taking a close look at the stories of Eretz-Israel author Yaakov Churgin (1899 - 1990) as a hybrid system of identities, that is ambivalent and unclassified, that can also fit stories about Jews of Ashkenazic origin as they were portrayed in the stories of the Jewish shtetls by authors such as Shalom Aleichem, Dvora Baron, Isaac Bashevis Singer, and Shay Agnon, while identifying the similarity between secular or enlightened Orientalism's attitude to traditional or religious society, and Ashkenazic Orientalism's attitude to the Mizrahi Jews in Eretz-Israel. The article will also suggest a new diachronic examination of the literary criticism regarding Churgin's writing in its ethnic context, that will review the primary criticism over the years and address the characteristics of this criticism in light of the changes over the years.
\end{abstract}

Keywords: Yaakov Churgin, ethnic ethos, Mizrahi Jewish figures, hierarchy of identities

\section{Introduction}

Yaakov Churgin was born in Jaffa in 1899. Among his contemporaries, Churgin was the only Hebrew Ashkenazic writer who was born, grew up, and educated in Eretz-Israel, like the Mizrahi authors Yehuda Burla and Yitzhak Shami (Bar Yosef, 1981). Aside from his book, Sipurim [Stories], for adults, he also published dozens of stories and folktales for children and young people. Another anthology of stories, Alumot [Sheaves], was published in 1957. In 1981, an additional collection of his stories, Yalkut Sipurim [A collection of stories] was published. Churgin passed away in 1990. Studying three of his books, written during different periods, Sipurim (1928), Alumot (1957), and Yalkut Sipurim (1981), shows most of Churgin's heroes to be Mizrahi Jews or Arabs. From an initial reading, it would seem these two groups have much that divides them. Mizrahi Jews in Churgin's stories are viewed as "Arab Jews" regarding their mentality and lifestyle, even though the Jews from Oriental countries saw two totally opposite identities here in regard to Zionism, and did not agree with spoken or written discourse identifying them as "Arab Jews". When first reading the stories, it appears further that Churgin shapes his Mizrahi characters as grotesque and primitive using derisive sentences, with their language and behavior testifying to a Levantine rabble, lacking in nationalist aspiration, totally subservient to a particular Orientalist definition and focused on their personal materialism. A cursory reading seems to show that Churgin was careful to preserve a hierarchy of ethnic, generalized, and racial identities, made the Mizrahi characters inferior to the Ashkenazic ones, and that his stories include complex relationships between the extremes of the semantic pattern of "Mizrahi and Ashkenazic Jews", while maintaining a cultural divide between them. (Note 1).

\section{Literature Review}

The literary criticism of Churgin's works can be divided into two main periods: the 1960s and the 1980s.

\subsection{Early Criticism}

At the beginning of his career as an author, Churgin was not accepted in the literary circles. It was argued that his political opinions were too right-wing and extreme. The conventions of taste that ruled literary criticism, with all their alternatives, also influenced whether Churgin's works for adults were accepted. His early writings were received with relatively favorable criticism and merited several positive reactions, but his anthology, Alumot, was met with reservation by the literary critics, and in essence his writings for adults were gradually forgotten during the years following the State's establishment (Bar Yosef, 1981). Some critics argued that his stories seemingly described the 
Eretz-Israel experience, but could have taken place anywhere in the world, and they are not folklore, nor do they represent ethnic characteristics, but rather serve as a basis for describing human behavior (Bar Yosef, 1981). In addition, Churgin was harshly criticized by critics such as Ben Eliezer, Rabinowitz, and Lifshitz.

Ben Eliezer (1944) negates the uniqueness of Churgin's writing. "The issue is not new: The same issues found in all the descriptions of family experiences, the relationship between a husband and wife, the war between fathers and sons, the little joys and sorrows" (Rabinowitz, 1971, pp. 41-62).

Additionally, Yaakov Rabinowitz (1971) does not mention Churgin at all among the writers who wrote in Palestine after the First World War. A normative claim that was accepted in Hebrew literary criticism was the demand for "rich language". In Rabinowitz's opinion, Churgin did not belong with authors such as Gnessin, Agnon, and Hazaz, whose works include a fascinating factor of rich language, that is enough to compensate for a static plot and generalized characters (Bar Yosef, 1981).

Liphshitz (1942) joins the 1960s criticism against Churgin: "Whoever reads Churgin's stories is not expected to rise up to a sphere of lofty thoughts, and will not even be endowed with a special emotional effect... you will immediately realize that the author did not struggle with complications of spirit and twisted situations".

\subsection{Criticism During the 1980s}

All of these opinions contributed to his work being pushed to, and even almost over, the sidelines until 1979. That year, a five-part series of articles about Yaakov Churgin by Prof. Gershon Shaked began to be published in the Yedioth Ahronoth literary supplement. Perhaps this is the first sign of the awakening of new interest in Churgin's stories. (Note 2).

During the 1980s, literary criticism of Churgin was divided into two: that of Lev Hakak (1981) who opposes any writing in general, and Churgin's in particular, that depicts Mizrahi Jews as "inferior" characters (Note 3), and of Hamutal Bar-Yosef (1981) and Gershon Shaked (1988) who do not view the representation of the Mizrahi characters in Churgin's stories as reflecting discrimination, inferiority, or ethnic orientation.

Hakak argues that not many authors arose for whom the Jewish-Mizrahi world was the focus of their life, and the authors of European origin did not usually write about the Mizrahi Jews' specific problems and experiences, although they have their own labels. If they did discuss them - they often understood the body but misunderstood the soul of what occurred, and entire chapters about the experiences of Jews of Oriental origin, hopes for the Redemption, misgivings regarding immigration to the Land of Israel, being torn between East and West, the emptying out of ancient Jewish communities, the collapse of tradition, the erasure of the old political limitations and drawing of new ones - all of these are barely echoed in the Hebrew literature of recent generations, relative to how similar events in the lives of Ashkenazic Jews resonated (Hakak, 1981, p.12). "The way Sephardic Jews are discussed in our literature is frequently based on stereotypes. Such stereotypes have their roots in a disdainful attitude toward the Sephardim, reflected in the literature" (pp.29, 31).

In Hakak's opinion, various stereotypes originate in hostility toward Mizrahi Jews. There are few writers who swam against the tide, like Eliezer Smoli, and described the pleasant life of the Mizrahi Jews. Various factors influenced the creation and continuance of different stereotypes regarding the Mizrahi Jews. One is the force of inertia. Another is the tendency to apply generalizations and inferences from the unrepresentative individual on the margins, to the whole.

Bar Yosef (1981) studies Churgin's writing differently, relating to the representation of, rather than the relationships between, ethnic groups in his works. She believes that the folk figures - Ashenazic and Sephardic, Jewish and Arab are portrayed non-exotically in Churgin's stories. "Nostalgia or romance, should they exist, are not turned toward the local tribal life but rather to the primitive as a general human characteristic."

Shaked (1988) adds to what Bar Yosef wrote and argues that there are many similarities between the three (Shami, Burla, and Churgin) - deep roots in Eretz-Israel, a direct affinity for the Arab Orient, openness to the Mizrahi culture, and more: "Undoubtedly, the three are a landscape pattern of their birthplace, who succeeded in describing that which was close to them from their childhoods, trials they had personally endured" (p. 68).

\subsection{Recent Studies}

Over thirty years have passed since the critical remarks about Churgin's works by Hakak, Bar Yosef, and Shaked. The study by Hever and Shenhav (2010) presents the entire perspective of the issue of the Mizrahi Jews in a different light. The study is not literary criticism, but rather in the field of sociology, that views the past from a different standpoint and can also shed light on the literary criticism. The researchers write that Arabism appears in Israeli society as a generic name for the national enemy (p. 60). Israeli society had difficulty in containing Jews with signs of Arab culture in their lifestyles, because of the sensitivity to "enemy" characteristics, and, therefore, attempted to erase their "Arabness". For 
this society, it was the measure of the success of the Zionist project. Its goal was clear: Arabness belongs to there, Jewishness belongs to here (Shohat, 2001, p. 332) (Note 4). It was feared that the line would be blurred, or that Arabness would trickle into Jewishness. Dividing the Jews and Arabs into two dichotomous categories, that do not meet in the Zionist discourse, was intended, therefore, to solve the problem of ambivalence and the threat created by the hyphenated category of Jewish-Arabs. Therefore, while multiculturalism was possible in many places in the world by creating a large expanse of new hyphenated identities such as Afro-American, this possibility was blocked in Israel for the Jewish-Arabs (Hever \& Shenhav, 2010, p. 63). The category which the national discourse sought to use to hide the Jewish-Arab group was the concept of ethnic groups. This concept delimits the concept of identity into communal-local limitations, with a cultural-folklore character. During their transformation into "Edot Hamizrah" (Communities of the East, Mizrahim), the Jewish-Arabs became Orientalized anew. This Orientalization simultaneously negated and confirmed their Arabness, thus also enabling maintaining the distinction between the categories of East and West. Hever and Shenhav argue that a new and broader Eastern discourse arose from the 1990s onwards, expressing more intervention by the second and third generation of Jewish-Arab immigrants (Yonah, 2005; Yonah, Naaman, \& Mahlev, 2007; Yonah \& Saporta, 2002): "In the end, the young generation cannot speak fluent Arabic, and the components of its culture have gone through cross-breeding and transformations so that there remains only a fragmented connection between them and their Arab source, and therefore the members of this generation cannot be Jewish-Arabs" (Yonah \& Saporta, 2002, p.64).

\section{Research Goals}

The aforementioned purpose of this article is to offer a new interpretation, from a distance of thirty-eight years from the last literary studies written about Churgin, a literary interpretation that connects to Hever and Shenhav's sociological study. The article will refer anew to the way Churgin chose to shape the Mizrahi character in his stories, and will examine the Mizrahi ethos and the effects of secularization on this ethos. Likewise, the article will attempt to address the following questions: Did Western culture or secularization affect the shaping of the world of values of Mizrahi Jews, or did it remain faithful to its tribal and traditional world? And if it did indeed remain within its tribal and traditional world, how is this faithfulness seen by Churgin, as an author who creates and shapes Mizrahi figures in his stories? How does each one of the characters, both Mizrahi and Ashkenazic, in Churgin's stories, try to appropriate the Israeli ethos of creating the "New Jew", which developed in Israel with the renewal of the Zionist idea, if they indeed do? And the main question that will be examined: Are the Mizrahi characters in Churgin's stories really portrayed as inferior, or does Churgin perhaps describe the Mizrahi culture that he knew personally (and not second-hand, as argued by many literary critics) together with its weaknesses and strengths? Is the feeling created that the Ashkenazic characters in his stories are superior in comparison to the Mizrahi ones?

This article will examine findings from the books: Sipurim [Stories] (1928), Alumot (1957), and Yalkut Sipurim (1981) on several planes and compare Mizrahi and Ashkenazic Jews in Churgin's stories in these anthologies: professions, class, attitude towards women, popular beliefs such as amulets, curses, evil eye, good luck charms and graves of the righteous, food and customs, and parent-child relationships (Note 5).

\section{Results and Discussion}

\subsection{Professions}

Many studies noted the connection between the low professional, economic, and educational stratification of the Mizrahi Jews as compared to the Ashkenazim (see, for example, Epstein, 2000). The 1950s Mizrahi immigration occurred during the middle of the state's industrialization process - a process during which the hegemonic group, the Ashkenazim "strengthened qualifications and education as the main criterion for employment, but the Mizrahi Jews' high school or academic certificates were not recognized when they came to Israel, so that others who emigrated to other countries were more successful than them in the employment field" (Yogev \& Shapira, 1992, p. 33).

Regarding professions, Churgin distinguishes between Mizrahi Jews, who are laborers, working in hard physical labor, such as water-drawers, fishermen, house painters, and a further assortment of casual labor, and Ashkenazic Jews who are employed in academia or public service: "Polishing shoes is for singles. He sold his red box and 'went out' to the market, meaning, he began working in all kinds of employment. He was a waiter in a coffee shop, a porter, a garbage collector, a bagel seller, an aide to a grave digger, and a watchman" ("Murdoch boneh bayit").

A synagogue sexton ("Yedido shel rabbi meir"), a fisherman ("Yaldei hakineret"), Yissachar the baker ("Yaldei hakineret"), Yissachar the greengrocer ("Leil yare'ah"), a housepainter ("Ad ziknah"), Ishah the washerwoman ("Hakham yishak oseh shalom"), and Mino the shoe polisher ("Hakham yishak oseh shalom").

The sole Ashkenazi in his stories who works in "Mizrahi employment" is Yujik the wagon driver ("Yujik ha'eglon").

In contrast, the Ashkenazic Jews are described as having totally different jobs: Paul the psychologist ("Antishemit"), 
Doctor Yisraeli ("Lavrak hayeri'ot"), Nurse Rivka ("Lavrak hayeri'ot"), teachers ("Ma'arbolet semuyah"), and a violinist ("Professor Leonardo"). Despite the fact that these professions are, perhaps, considered more respected in society, Churgin actually includes covert criticism, specifically against the Ashkenazic professionals.

In the story "Antishemit" [Anti-semitic] in Alumot, Grada tells about her son Peter, who "works in a garage and earns a living. A true Sabra [native Israeli]". Meaning, when she thinks that perhaps the work is not sufficiently respectable, she adds the description "a true Sabra". Arella's parents are described thus: "Arella's father was the director of a well-known political party institution. The select language together with the well-groomed office handwriting testified to conceit and a generous measure of arrogance". Arella's mother was a pianist, "who performs in concerts and receives positive appreciation in the press" ("Sodah shel Arella" [Arella's secret]). Here Churgin explicitly uses the word "arrogance" to describe Arella's father, and to the description of her pianist mother, who is given positive appreciation, he attaches a lover, who takes up most of the mother's time and attention instead of giving it to her daughter, Arella, when her husband is away from home. After Arella discovers her mother's romance, Arella tries to commit suicide. A broken family is portrayed here - a father, mother, daughter, and lover, with nothing similar among the Mizrahi families in Churgin's stories. Professor Leonardo ("Professor Leonardo"), a violinist, is also described as a ludicrous, haunted, and ostracized figure. The antithesis of violinist Leibel-Leonardo's seemingly cultural philosophy, that of the Jewish boy who studied in Europe and arrived in the Neve Tzedek and Neve Shalom neighborhoods of Tel Aviv, and of the poor world of the residents, creates a series of grotesque events (Ekrony, 1982).

And perhaps Churgin's goal in this division into "Mizrahi" and "Ashkenazic" professions is simply a result of a romantic, Zionist perspective criticizing the bourgeois class that abhor manual labor, since we know that Ashkenazim also worked in physical labor.

\subsection{Class}

Regarding the issue of Orientalism, Khazzoom (1999) argues that the Orientalist process in Israeli society actually began with the Jews of Central European origin labelling the Jews from Eastern Europe as "Eastern" Jews (Ostjuden). She writes that the Eastern European Jews, in turn, labelled the Jews from Islamic countries as "Eastern" [Mizrahi] and excluded them from the classes with influence in Israeli society, since they were unsure of their standing due to their own previous branding.

Churgin's heroes' professions also lead to the creation of differing status between the Mizrahi and Ashkenazi Jews. In the anthology Sipurim, all the characters are Mizrahi and are depicted as pitiable, poor, and penniless. In Alumot, some of the characters are Mizrahi, and some Ashkenazic. Most of the Ashkenazic figures have higher social and economic standing. Thus Haim, the cowshed and henhouse owner in the story "B'tsel halefufit" [In the shadow of the morning glory], and the homeowner Yeshaya-Tzvi in the story "Ad ziknah" [Until old age], in which his daughter is described "in her rich festival dress and her plethora of sparkling jewelry", and the Passover Seder table in their home is also depicted as set and laden with plenty. But do those from the upper class in these stories enjoy satisfaction and happiness? Do they live a life of joy and fulfillment from what they do? Every reader discovers that under the mantle of wealth and luxury hide wretched figures, far away from happiness. It is actually the Mizrahi characters in Sipurim, with all their poverty, who experience far more moments of joy, satisfaction, and fulfillment from the simple things of everyday life: the various ceremonies, their beloved traditional ethnic foods, in creating a space for leisure time, despite the battle for economic survival.

Perhaps here, too, Churgin's outlook is the distinction between bourgeoisie and low economic standing, irrespective of ethnic origin, emerging from a romantic vision of economic want testifying to a person's characteristics, such as modesty and being satisfied with little as against financial wealth that testifies to haughtiness, scorn, and arrogance.

\subsection{Attitude Towards Women}

In most of Churgin's stories, the attitude to women is discriminatory and unequal. Churgin does not deviate in his writing from the then prevailing belief about women's position, when most women - not specifically Mizrahi women lived in patriarchal and repressive societies, that did not allow individual expression, and thus did not empower women or recognize their value (see many studies about the status of women during the period before and during the establishment of the State of Israel, such as Bernstein (1987, 2008) and Berlowitz (2003)). This attitude is more recognizable regarding the shaping of the Mizrahi figures than the Ashkenazic ones, but it is interesting to note that the cloak of external chauvinism hides the men's dependence on their wives, and a great deal of wisdom of the women themselves, who find their own ways to earn appreciation, express opinions, and receive fair and respectful treatment. Using their own quiet, small revolutions, they know how to get what they deserve. Here are several examples:

Shmaya, in the story "Yedido shel rabi meir" [Rabbi Meir's friend] discounts Rahel, "Shmaya didn't pay heed to Rahel's fears. 'Woman...!' Shmaya would argue, that Rahel did not know how to educate Meir. And there is nothing to 
wonder about. Rahel - is a woman." However, when Rahel seeks to educate their son Meir differently to what his father wishes, so that he will not have a trade, but will be a Torah scholar, Shmaya fulfills her request and turns to the Torah teacher: "Rahel, my wife Rahel, wants Meir to specifically be a scholar. Not a carpenter, not a blacksmith, but a scholar. Woman...!" Despite the fact that he negated her personality with the word "woman!" at the end of every sentence, when speaking about his son's education, he does what she says.

Hakham Yitzhak ("Hakham yishak oseh shalom" [Hakham Yitzhak makes peace]), also negates Sa'adah, his wife with the word, "Woman!": "With this gullible woman believing that sugar was only created for coffee and baked goods. Woman."

The misogynic attitude to women is also towards other women. On his way, he meets Ishah the washerwoman and to begin a conversation he sticks his sharp and nailed stick into her ribs. And about his hated daughter-in-law, he says: "A crushed flea, filth daughter of filth, a witch, a woman 'without roots"'. He enters the home of his son, who he has not spoken to for a long time, when the son is not at home, and because he also does not speak to his daughter-in-law, who caused the whole dispute with his son (according to him), Hakham Yitzhak uses the baby, his grandson, to send messages to his daughter-in-law: "Tell your mother that she is very evil, that there is none as evil as her among women... that it is better for her to be silent, that she is the only one guilty in all the arguments between us, that she is a contentious woman. Tell her and do not fear...' The baby calmly sucked his fist and showed no interest in the strange conversation between his mother and his grandfather." When his son returns home, he drags his son and daughter-in-law by their ears to his wife and rebukes them that they need to make peace between them. Throughout the story, we see Hakham Yitzhak's humiliating attitude towards women - towards his wife, Sa'adah, his neighbor Ishah, and his daughter-in-law.

But there are also exceptions. Stories in which the Mizrahi woman is the mistress of the house and beats her husband, even if it is as a joke, as in the story "Leil yare'ah" [A moonlit night]: “"Three red burns on your tongue, drunkard!' Rivka pretends to be very insulted and angry, and brings down her two long, awkward hands on her husband's two shoulders."

In contrast to this attitude towards women in painting the Mizrahi figures, Churgin describes other relations, seemingly, when creating the Ashkenazic characters. For example, in the story "B'tsel halefufit", Haim and Meira discuss how to educate Gidona, their daughter. The discussion is relatively egalitarian:

"What do you say about the little one's questions? She's a real philosopher! - That means we need to give real answers. - And you never let me answer her!"

It would seem it is difficult for Haim to accept the new times, in which the status of women has changed, but it is hard for him to distance himself from the education he was given at home: "Leave your stupid questions!" Haim's father answers his mother when he asks about the names of the places they are passing through, and she wants to know the names of her granddaughter and daughter-in-law. And therefore, sometimes Haim also answers his wife, Meira, "Patience! Without sentimentality!" He calls out to her when she shows interest in the difficult calving of their cow, Shoshanna.

It is clear that the Zionist ethos occupies the Ashkenazic figures (see, for example, "Antishemit"), as opposed to the husbands' completely different criticism of their wives in Churgin's stories, where the criticism is more of how the wife functions in the home, and her gender-based status as "a woman", with her having no connection at all to political issues outside the realms of the kitchen, having children, or her sexuality.

As opposed to Mizrahi women in Churgin's stories, who are humiliated, but achieve what they want slyly ("Eliyahu hakatsav" [Eliyahu, the Butcher]), Ashkenazic women "dare" to criticize their husbands in public, such as Mrs. Bamberger who rebukes her husband for eating too many candies and he sits admonished "while surreptitiously finishing eating the last pieces that were in his mouth". Later he retorts, "She doesn't let me live!" ("Antishemit"), criticism that would never have been said in Sipurim, in which in all the stories the husband's Mizrahi figure eats as much as he wants, without his wife interfering in his nutrition.

Regarding courtships, Churgin describes courting that is a little violent, forced, and demanding when shaping the Mizrahi characters in his stories (in Sipurim, for example), as opposed to more gentle courting when describing Ashkenazic figures. Doctor Yisraeli (note the Israeli name) and Nurse Rivka only exchange glances in the operating room; later he accompanies her, they sit on a bench, are silent, and look at the scenery. He tells her that he is a Holocaust survivor and his wife and son were murdered. She tells him that she is also a Holocaust survivor. Her young husband and all her family were all wiped out, aside from her only son, who, it later turns out, is not her son but actually his, who he thought dead, and she adopted him as her son after the Holocaust. He gently proposes marriage so they will both be the child's parents ("Lavrak hayeri'ot"). This also presents the Zionist ethos in its mention of the events of the 
Holocaust that the Jewish nation endured.

We can see from these examples that the attitude towards women is different in the two ethnic groups in Churgin's stories, but despite the different attitude, Ashkenazic women were also degraded in various ways, and neither were they excluded from the stereotypes that clung to them. In both ethnic groups, both the Mizrahi and Ashkenazic women know how to steer their way out of conflicts and complex situations and have the upper hand, aside from one exceptional story, "Murdoch boneh bayit" in which a woman is left beaten and humiliated throughout the story, but is described in a way that awakens empathy from the reader. At the end of the story, when Murdoch invests all his money in buying an apartment and wakes up the next morning regretting his purchase, it is impossible not to feel the cynicism, rejection, and criticism that his character arouses among the readership, and Churgin's purpose in leading the plot to such an end.

\subsection{Amulets, Curses, the "Evil Eye" and Magic, Graves of the Righteous}

To understand the ancient traditions of amulets, evil eye, magic, and praying at the graves of the righteous, it is important to elaborate on their meaning before examining these ideas from a literary perspective in Churgin's stories. The phenomena of magic (Harari, 2011, p. 41) and mystery are, as aforementioned, ancient (Davis \& Frankel, 1995, p. 9). These phenomena have been part of the daily lives of humanity from early times. Early man, when exposed to earthshaking events, looked for an explanation and meaning in what he saw. His experiences were translated into the language of signs, through which he sought to provide meaning for what befell him and disturbed him, so as to construct a fence to protect him from harm. In his article, Harari (2011, p. 14) notes that "we cannot deny the long-time presence of magic in Jewish tradition in its many expressions". No one argues that Judaism had folk medicine that used all kinds of magic - spells and sorcery (Harari, 2010, p. 6) and even employed amulets as sacred and auspicious objects. It should be noted that Jewish society at the time of Churgin's writing was a poor one. Their difficult situation left them with no choice but to seek out help and salvation using supernatural means.

Alongside the rabbinical literature, there is also folk literature and sayings that reflect the "place of beliefs in supernatural powers in the world of the Jews of the Ottoman Empire" (Ben-Naeh, 2006, p. 90).

The phenomenon is common within Judaeo-Spanish society; they believed in supernatural powers and were extremely superstitious (Saba-Wolfe, 2011, pp. 124-159), using amulets, fortune telling, using amulets and saying praises (Alexander \& Papo, 2011, p. 15).

The first documentation of the phenomenon of magic is found in books about the Creation of the world and of Man in various cultures. In Jewish tradition, it is documented in the stories of Genesis and in the Bible, to which interpretations and homiletic interpretations were added over the generations. The list of sources include the stories of the Sages (Harari, 2011, p. 33) that describe the magical forces of rabbis to exert control using powers of magic.

During the second half of the 19th century the researchers began to distinguish between religious values and ceremonies and folk beliefs and superstitions (Harari, 2011, p.13). The researchers noted how the folk beliefs and good luck charms had developed.

Such beliefs were more prevalent in the East and throughout the Ottoman Empire, than in Western Europe. Most of the ceremonial objects are simple and useful vessels, made from simple materials - earthenware pots or items from nature. For example, earthenware bowls for magic; metal plates - copper, silver, and gold; quarried substances and precious stones. The amulet is usually a tangible or personal object, such as a stick, rod, or ring.

All the objects noted above bear no intrinsic significance, and their only significance lies in that imparted to them as a result of the beliefs the person develops and the tendency to ascribe them with particular characteristics or auspicious properties. The scrap of paper or parchment has no importance, the amulet draws its importance from the text inscribed upon it. In light of the many objects serving as amulets, we can see how common their use was. Tangible evidence of varying magical activity exists in the form of objects that draw their strength from the magical association granted to them by the priest or sorcerer (Harari, 2011, p. 18), who were experts and considered "people who could make spells". They blew and breathed a holy spirit into the object-amulet and thereby imparted the object with special power. The object-amulet became a shield and buffer against enemies and evil spirits that were trying to harm the person who carried the amulet.

Most of the amulets were primarily written for healing, a wish for protection from enemies and evil spirits, love, success, and a good livelihood, and they are characterized by oaths taken from biblical sources, and, in particular, various combinations from the Book of Psalms, that turn the psalms into a recipe for spells (Harari, 2011, p. 38).

Such things do not appear in Churgin's books at all when describing the Ashkenazic characters, but only regarding the religious Mizrahi characters. The article will bring a number of examples, and then explore Churgin's purpose in 
ascribing this phenomenon only to Mizrahi Jews ${ }^{1}$ :

\subsubsection{Graves of the Righteous}

"Murdoch does not fear. There is Rabbi Meir. And there is also Maimonides. There is no fear" ("Murdoch boneh bayit").

"He had a friend, Shmaya the beadle, a great and respected friend, and he trusted in him, that he wouldn't leave him. Is he not Rabbi Meir Baal Hanes [the miracle worker]?" ("Yedido shel rabi meir").

\subsubsection{Hamsa}

"On every wall there is a whitewash drawing, possibly a broom, possibly a splayed hand - a Hamsa - to guard against the evil eyes. Every window has an eggshell hanging on it to guard against collapse" ("Murdoch boneh bayit").

"Shmaya made for his only son, Meir, a wonderful cradle. With his own hands he built it. He painted it in bright red. And put a spread-out Hamsa at its head and drew frightening Hamsas in blue and in whitewash on each of its sides" ("Yedido shel rabi meir").

\subsubsection{Amulets and Various Charms}

"And when the dead did not answer her, the woman began to seek out the living - the various kinds of magicians and those who knew how to use spells. And once an old Mugrabi (Western) magician gave her a bottle full of strange liquid - a spiritual catalyst for pregnancy. He ordered her to drink a cezve-full of the drink every time she heard the sound of the muezzin above the nearby mosque. And at the end of the month of Ramadan, the salvation will come" ("Yedido shel rabi meir").

"Here he is approaching Aziza his little child, on whose neck hung a large, heavy chain of amulets and other strange lucky charms" ("Yaldei hakineret").

\subsubsection{The Evil Eye}

"How many evil eyes there are in the city - and what does he care? Don't you know the eyes of Jamilla, the old Kurdish woman, the woman who bewitched her husband and smote him with blindness? - Fire and demons! Demons and fire!" ("Yedido shel rabi meir"). Rahel, Shmaya's wife is afraid when he goes outside with the baby.

"But don't say too many praises, because of the evil eye" ("Yaldei hakineret").

\subsubsection{Curses}

"His kind eyes always bulge out of their sockets, flashing fury and hate - and he screams curses at the top of his voice Wicked man! Amalek! Villain! Stand up! Die! God willing!” (Hakham Shlomo. Hakham Shlomo curses the vehicles that bother him, and feels great hatred towards them.)

"Wanton! Cursed! He should destroy his grandfather's home" ("Yaldei hakineret").

\subsubsection{Popular Superstitions, Demons, and Spirits}

"Behold something white is shining on the sea from afar, skipping and singing in a woman's voice - it is surely the mother of the Lake of Galilee... the terrible she-demon! She is white and cold as a corpse. Her hair - green and whistling and twisting water snakes; her eyes - two winter nights sealed and cold, and she had a pharynx like a whale that swallows all the fishermen with their boats... ("Yaldei hakineret").

It appears that Churgin's aim in creating Mizrahi characters where they, their deeds, their actions, and their conversations are ruled by the world of magic, is to inject a touch of mystery into their simplicity, their innocence, a spiritual world which includes human transition and dedication ceremonies, a world of the subconscious and faith in supernatural capabilities. Beyond the fact that these descriptions advance the plot in Churgin's stories, and document an entire world that oscillates between theology and demonology, Churgin himself is greatly attracted to this world with bonds of magic and romance, which are part of the colonial process and do not contradict it (Note 6.).

\subsection{Food}

The system of food is a language, and mainly an encrypted one (Barthes, 1975; Levi-Strauss, 2004). There are messages encoded in cooking and eating, and women are those who understand them. In its essence, the code provides a range of possibilities for sending unique messages, with their solving dependent on the social and personal context in which they are passed on. It is clear from his descriptions of food from the Mizrahi kitchen that Churgin was greatly attracted to

\footnotetext{
${ }^{1}$ It is known that there are various folk beliefs among Ashkenazic Jews too (see, for example, the stories of Isaac Bashevis Singer (such as Satan in Goray)).
} 
this cuisine through its abundant dishes with aromatic odors that tempt the eye and palate, and this is part of the colonial perspective in the east-west relationship:

"They had candies and roasted chickpeas thrown on them from the stores and homes" ("Yedido shel rabi meir"). "They tasted almond jelly, which Rahel had made during her pregnancy, split open watermelon seeds and peanuts, drunk plenty of water - and it was good" ("Yedido shel rabi meir", the circumcision feast for Shmaya's son).

"And it aroused in him a great desire for a good and lavish Sabbath meal, a sheep's stomach freshly stuffed with rice and pine nuts, and seasoned with black pepper and parsley!" ("Yaldei hakineret").

In addition, Mizrahi men are portrayed as having strong desires regarding food; they crave certain foods and do not ask their wives whether to taste a particular food, whether they can or cannot. Just the reverse, their wives fulfil their wishes regarding everything culinary. In contrast to all the above examples from Mizrahi men, a single example exists of Heinrich Manheim (the Ashkenazic Jew) who loves candies, despite the fact that his wife forbids him to eat them and he eats them surreptitiously ("Antishemit"). In Churgin's stories in the anthologies discussed in this article, the Ashkenazic kitchen is not described at all.

\subsection{Parent-Child Relationships}

Families undergoing cultural transition and families in an employment-economic crisis are examples of the reflection of social processes in familial relationships. The Israeli family-centeredness of this type has always been supported by two main widespread approaches in Israeli society: the religious and nationalist approaches (Fogiel-Bijaoui, 1999). In all ethnic and religious groups in Israel, family-centeredness originates with a religious track and is supported by the nationalist perspective, meaning that family-centeredness is a nationalist asset.

In Churgin's stories, the Mizrahi fathers threaten, sometimes beat their wives and children, impose their authority, and curse, but in the end, in most cases, they are loving, caring fathers who try to fulfill their children's wishes:

"He hints to his wife to move aside, approaches his son, puts on an angry face, makes his little eyes bulge, and orders threateningly - Eat you little bastard! Meir is scared of his father's voice and his strange expression and answers with unceasing cries" ("Yedido shel rabi meir").

"Afterwards he slaps the nape of his son's neck, and laughs loudly: 'May your house be destroyed, you little bastard! You really are clever, little bastard!" (In the story "Yedido shel rabi meir", Shmaya is amazed by his little son who learned how to write.)

Eliyahu, the butcher, in the story "Eliyahu hakatsav" (Yalkut sipurim), decides to beat his son once a week, for no particular reason, so as to educate him, even if he did nothing: "Eliyahu decided and determined that he would whip his son once a week, on Friday afternoon, aside from the beatings he generously disperses to him for every sin and mistake... a tradition is a tradition and it should be ensured in the future too..." He even appoints his father and young daughter to tell him when Yaakov, his son, arrives, so that he will not escape the weekly whipping. Yaakov climbs a tree and the father and son begin to negotiate how many lashes he will get if he comes down then. In the end, Eliyahu leaves the whipping to his father, Yaakov's grandfather, and he takes him into his hut and makes it sound as if he is whipping him. A secret covenant between the grandfather and grandson, including feigned crying. In contrast to the son, Rahalina, Eliyahu the butcher's daughter is most beloved to him: "Rahalina is Eliyahu's beloved. Even though he was very angry at her mother when she was born, for giving him a daughter and not a son" he particularly loves the way she speaks, when she exchanges $s h$ for $s "$.

The exception is Murdoch he remains a violent husband and father throughout the story ("Murdoch boneh bayit"). "His father did not act generously, and said to his daughter-in-law, who had come to ask him for food: "Eat each other and be satiated!" "Leave it, Nehemiah, I will break your hands" ("Murdoch boneh bayit").

In Churgin's books, the Ashkenazic families have totally different parent-child relationships. The parents are far more patient, the education regarding values is different, there are more conversations between parents and children speak and they answer the children's needs, even when they ask lots of questions. But beneath the various cloaks, that come to seemingly show better parent-child relationships, hide families who are not necessarily happy.

Here are several examples:

“'She will never get up again - never, mother? Mother, tell me: Who is more important, the cat or the chicken?'... Haim tries to stop the girl asking questions, but Meira answers patiently. The girl's determination to take the chicken out of its grave is obvious". Little children from Mizrahi families in Churgin's stories are not painted as particularly curious or askers of questions in the way Gidona too asks her mother many questions in the story "B'tsel halefufit".

And when Gidona insists on playing with the chicken carcass, her father explains to her why it is dangerous: "We cannot leave a carcass in the house, because it will start to smell and poison the air!" And he throws the chicken carcass away. 
The father also demonstrates his concern for his daughter: "Don't forget to close the blind next to Gidona's bed well!" "This time his head is full of his great worry and concern - Did Meira close the blind?"... "He paces in his sleepwalk up to Gidona's bed, checks with the uncertain movements of a sightless man whether the blind is closed, returns, and falls with a loud thud onto the bed."

Gidona, the girl, is also described as someone who likes looking at books, even though she does not know how to read. Meaning, Churgin portrays a home in which books occupy a respected place and there are bookshelves, something never mentioned when describing the homes of the Mizrahi families:

"And she enters the house stealthily, takes a large book that Father often studies off the shelf, and tiptoes outside."

When Haim's parents come to visit, the granddaughter, Gidona, becomes close to the grandfather and communicates with him better, to the grandmother's distaste: "Gidona doesn't leave Grandfather alone for a minute. She put down the doll and the big book - Father's book - and also forgot about the henhouse and the cowshed. Her small hands hold onto his coat, afraid he will get up and flee."

When his father disturbs Haim with his questions while Haim is milking, Haim responds: "'I'm busy now, Father, and you are disturbing me with your questions! Go and walk around the yard a little until I've finished!' 'Shut up, you insolent son!' Grandfather raises his voice while placing a look of firm authority on his face - 'Do you think you have grown up and now you can give your father advice? Davasha! Bring me my belt and I will teach this young devil how to behave!' 'May God be with you, Shlomo!' Grandmother, who understood what he said as literal, gets nervous. 'Are you crazy? Woe to you, fool! You fool!' - Grandfather waves his hand and nods with his head toward her to negate what he had said, and once again his loud laughter fills the cowshed". From this dialogue between father and son, and between father (the grandfather) and mother (the grandmother), we learn about a different culture of honoring parents, completely different from the Mizrahi families in Churgin's stories. The son dares to tell his father that he is disturbing him while he works, the father tries to restore control, to be the authoritative figure who will decide in the home, as he was when Haim was a little boy, but the grandmother's reaction brings him to rescind what he said and turn it into a joke.

The grandmother's worry for her son ("Hayidishe mama"), even after he is already married and has a daughter, who refuses to let her son be independent, does not appear in the stories about Mizrahi families, certainly not regarding older and married sons: “'Won't you wear a coat, Haim!' grandmother calls after him, 'Tell him yourself, Shlomo!' She approaches her husband for help, since the son does not listen to her. 'He'll catch cold... he thinks he's an adult...I can still sit him on my lap!"”

The generational gap in this story is expressed in the father's wish to preserve tradition, and the son's wish to create a "New Jew" who is not a Diaspora Jew, a "New Jew" who is cut off from his ancestors' tradition and attempts to create a new secular culture in Eretz-Israel, a culture of settling the land, work, and manual labor. This is an example of the struggle of Sabbath observance between Haim, the son, who goes to milk the cows on the Sabbath as on the other days of the week, and his father, who views the desecration of the Sabbath with great severity: "'I didn't forget, Father...' Haim answers with the serenity of someone certain that he is right, 'but this work has to be done'. 'Has to be done?!' the grandfather repeats in a distant voice, as a weak echo, 'But today is the Sabbath, my son, the Sabbath to the Lord..." The rocky relationship between father and son because of Sabbath observance also effects the granddaughter, Gidona: "Gidona feels the change, even though she doesn't know its cause. The girl is touchy and began to react to every little comment from her mother or father with screaming," and when she sees Grandfather crying about her father's Sabbath desecration after a harsh and uncompromising exchange of words by the son in contrast to the terrible sadness in what the grandfather said, she turns to her parents: "'You are bad children... I will be angry at you forever'... and she galloped back indoors. Immediately a quiet, angry cry is heard from there - Gidona is crying." Only when the grandfather expresses his wish to live far from his son, so as not to see his Sabbath desecrations, Gidona expresses her anger regarding this decision by showing open affection specifically to her grandmother.

But perhaps Arella's crumbling Ashkenazic family in the story "Sodah shel Arella", serves as one of the best examples in Churgin's stories of his criticism of the education, culture, and lifestyle in the Ashkenazic family - that represents, perhaps, the "elite", but evil winds blow sometimes deep inside, as compared to the naive Mizrahi family where preserving the traditions and honoring parents was of primary importance. This story describes Arella's alienated parents. Her father is overseas and her mother asks her not to bother her with school meetings regarding her daughter's scholastic situation. The daughter, Arella, is often absent from school, frequently throws tantrums, and eventually tries to commit suicide when she discovers her mother with a strange man (Alumot, "Sodah shel Arella"). Arella follows her mother, and thereby misses school, because she is suspicious that she is betraying her father, who is overseas, with another man. "She is sure that he is an old, ugly fool, that he is a disgusting monster. And her father is young and handsome; certainly the best-looking man in the world." This is kind of a daughter falling in love with her father and protecting his honor, while feeling hatred and animosity for her mother, who is suspect to her. And when Arella faces 
her mother with the truth - that she saw her with a strange man, her mother throws at her that her father also cheats on her with his secretary. Arella runs to the office, and someone tells her there that the secretary got married and has already left. When Arella returns home, she hugs the picture of her father - who is still overseas - and says, "Daddy... my sweet Daddy... I knew that you would never do such a thing to me... I love you so much... thank you, my Daddy". By using the words "such a thing to $m e$ ", Arella wants to say that had she discovered that her father had cheated on her mother, he would actually have been a traitor to her.

\section{Conclusion}

In the stories discussed here, the article shows us a huge gallery of Mizrahi characters with their human failings - some described with artistic and lingual expression in brief, some at length, but at the same time Churgin succeeds in creating the character of the Mizrahi Jew and delves into his inner world, dreams, doubts, and the depths of his soul. This creation comes at the expense of describing external background, such as landscape, time, and place. Churgin invested most of his writing in shaping characters and their internal world with a host of details connected with their life experiences, which he drew from watching their lifestyles and familiarity with their values, customs, and life events. Churgin sets his characters first and foremost as acting out of internal motivation. They do not adopt any kind of ideology for themselves, they are not connected with the people or nation, and they are not inspired with nationalist arousal. They are totally closed off within themselves, their personal desires, and the struggle for survival. It is clear that Churgin studied the customs of the Mizrahi Jews in depth, understood the variations, the scenes, the internal events within the Mizrahi Jewish society, and their special melody (he was born, as noted, in Jaffa, and wrote about a culture that was both physically and geographically close to him). There is a concentrated artistic view here that pierces the character's obscurity and shapes it. The spiritual and physical world of every one of the characters reflects tormented figures hoping for a different, better life - emotionally, spiritually, regarding their family, and even materially, with the giant chasm between their dreams and their ability to realize them remaining as a backdrop to the stories. During an initial reading, it seems that every one of the characters has defects that cannot be healed or bridged through interaction with their surroundings. This article specifically emphasizes that Churgin's characters are round, they undergo change in understanding their role in the world, their reactions, development, and opinions. While shaping the characters, he describes the different statuses and social strata in the nation. The activities in the story are many and varied: arguments, fights, unrealized love, intergenerational gaps that seemingly express the flaws in the characters, but actually play an advantage regarding the story's artistic flow and Churgin's ability to present the Mizrahi world together with all its details.

The criticism of his books swings between acceptance and rejection, but gives the impression that the rejection was created while placing Churgin into the category of stereotypical authors, without exploring the real motives Churgin employed when creating his Mizrahi figures. The article emphasizes that Churgin was actually motivated by documenting a culture that fascinated him and pulled him towards it with ropes of fear and curiosity, and not necessarily a motive of victory over the culture that he scorned. Moreover, perhaps he had the additional motive of awakening the Mizrahi Jew who was buried in the struggle for personal survival, to the national struggle and a general, national, and communal arousal. His writing is no different from that of authors who described the characters from the shtetls of Europe and their squalor, poverty, customs, and beliefs. Just as such writing was accepted without suspicion of it as touched by stereotypes, but rather as documenting what happened, thus we need to refer to Churgin's writing as he describes the Mizrahi characters.

\section{References}

Alexander, T., \& Papo, E. (2011). Kesem Hamagiah. Mekharim bemagiah yehudim sefaradit [Sephardic magic: Studies in Jewish Sephardic magic]. El Prezente - Studies in Sephardic Culture, 5, 9-33.

Bar Yosef, H. (1981). Introduction. In Y. Churgin, Yalkut sipurim [Collection of stories]. Tel Aviv: Yahdav.

Barash, A. (n.d.). Letter to Burla. (17/16248). Gnazim Archives, Tel Aviv.

Barthes, R. (1975). The pleasure of the text. (R. Miller, Trans.) (pp. 47-59). New York: Hill and Wang.

Ben Eliezer, M. (1944, November 2). Sefer hapartsufim [The book of faces, about beneficiaries]. Haaretz.

Ben-Naeh, Y. (2006). Migdar nashi betakanot b'inyaney mussar shel yehuday ha'impiriya ha'otemanit [Feminine gender and its restrictions in the ethical regulations of Ottoman Jewry]. Pe'amim: Studies in Oriental Jewry, 105/106, 127-149. Retrieved from https://www.jstor.org/stable/23429550

Berlowitz, Y. (Ed.) (2003). She'ani adamah v'adam: Sipurey nashim ad kum hamedinah [I am soil and man: Women's stories before the establishment of the state]. Tel Aviv: Hakibbuz Hameuchad.

Bernstein, D. S. (1987). Ishah b'erets yisra'el: Hash'ifah leshivyon bitkufat hayishuv [A woman in the Land of Israel: The aspiration for equality during the Yishuv period]. Tel Aviv: Hakibbutz Hameuchad. 
Bernstein, D. S. (2008). Nashim bashulayim: Migdar ule'umiyut b'erets yisra'el hamandetorit [Women on the margins, gender and nationalism in Mandate Tel Aviv]. Jerusalem: Yad Ben Zvi.

Davis, E., \& Frankel, D. A. (1995). The Hebrew amulet: Biblical-medical-general. Jerusalem: Institute for Jewish Studies. https://doi.org/10.1017/S0364009400010102

Ekrony, A. (1982). Havai erets yisra'el b'reishit hame'ah [The Eretz-Israel experience at the beginning of the century]. Moznaim 55(6), 50-51.

Epstein, N. L. (2000). Mishpahah v'reebud: Defusey shi'atuk shel i-shivyon beyisra'el [Family and stratification: Reproductive patterns of inequality in Israel]. In M. Mautner (Ed.), Tsedek halukati beyisra'el [Distributive justice in Israel] (pp. 121-148). Tel Aviv: Ramot - Tel Aviv University.

Fichman, Y. (1952). Bnei dor: Mesaprim, meshorarim, ishim [Members of the generation: Storytellers, poets, people]. Tel Aviv: Am Oved.

Fogiel-Bijaoui, S. (1999). Mishpahot beyisra'el: Bein mishpahtiyut lepost-moderniut [Families in Israel: Between familism and post-modernism]. In D. Izraeli, A. Friedman, H. Dahan-Kalev, S. Fogiel-Bijaoui, M. Hassan, H. Herzog, \& H. Naveh (Eds.). Min, migdar upolitika [Sex, gender, and politics] (pp. 107-166). Tel Aviv: Kav Adom, Hakibbutz Hameuchad.

Hakak, L. (1981). Yerudim vena'alim [Inferior and superior]. Jerusalem: Kiryat Sefer.

Harari, Y. (2010). Hakishuf hayehudi hakadum: Mehkhar shitah, mekorot [Jewish magic: Study, method, sources]. Jerusalem: Yad Ben Zvi and the Bialik Institute.

Harari, Y. (2011). Magiah yehudit: Mitveh v'he'arot [Jewish magic: Outline and comments]. El Prezente - Studies in Sephardic Culture, 5, 13-32.

Hazaz, H. (1958). Ofek natui [Extended horizon]. In H. Hazaz, Hagorat mazalot [A strap of astrological signs]. In Tel Aviv: Am Oved.

Hever, H., \& Shenhav, Y. (2010). Hayehudim-ha'aravim: Gilgulo shel musag [Arab Jews: The metamorphosis of a term]. Pe'amim: Studies in Oriental Jewry, 125-127, 57-74.

Khazzoom, A. (1999). Tarbut ma'aravit, tiyug etni usegirat hevratit: Hareka le'I hashivyon [Western culture, stigma, and social closure: The origins of ethnic inequality among Jews in Israel]. Israeli Sociology, 1(2), 385-428.

Levi-Strauss, C. (2004). Mitologogiyot: Hana vehamevushal [Mythologies: The raw and the cooked] (pp. 311-326). (Y. Reuveni, Trans.). Tel Aviv: Nimrod.

Liphshitz, A. (1942). Hasipur ha'eretsyisra'eli: Ksat sikumim vesikuyim [The Eretz-Israel story: A few conclusions and chances]. In I. Zarchi, E. Hamenahem, \& H. Toren (Eds.), Yalkut Yerushalmi ledivrei sifrut [A Jerusalem anthology of literature]. Jerusalem: Ahiasaf.

Miron, D. (1960). Adam v'nof besipurei yitshak shinhar [Man and landscape in the stories of Itzhak Shenhar]. Jerusalem: Bialik.

Rabinowitz, Y. (1971). Hasifrut ha'ivrit b'erets yisra'el [The Hebrew literature in Eretz-Israel]. In Y. Cohen (Ed.), Masluley sifrut [Literary tracks]. Tel Aviv: M. Neuman and the Hebrew Writers Association.

Saba-Wolfe, R. (2011). "Un ruah ke entro en una mosa": Poverty and morality in spirit tales by Rabbi Eliyahu Ha-Cohen Ha-Itamari. In El Prezente - Studies in Sephardic Culture, 5, 121-160.

Shaked, G. (1975). Mavo linekamat ha'avot shel yitzhak shami [Introduction to Yitzhak Shami's "Vengeance of the fathers"]. Tel Aviv: Yahdav.

Shaked, G. (1988). Hasiporet ha'ivrit 1880-1980 b'arets uvatfutsa [Hebrew stories 1880-1980 in Eretz-Israel and in the Diaspora] (Vol. 2). Tel Aviv: Hakibbutz Hameuchad.

Shami, Y. (1928). Nikmat ha'avot [Vengeance of the fathers]. Jerusalem: Mitzpeh.

Shohat, E. (2001). Zikhronot asurim: Likrat mahshava rav-tarbutit: Asufat maamarim. [Taboo memories: Towards multicultural thinking]. Tel Aviv: Keshet ha-Mizrah.

Shohat, N. (1971). Bein or lehoshekh [Between light and darkness]. Tel Aviv: Aleph.

Singer, I. B. (1955). Satan in Goray. New York: Noonday Press.

Yogev, A., \& Shapira, R. (1992). Miskal u'rekhishat status: Hebetitm adatiyim behitpathutah shel yisra'el k'hevrah masmikhah [Educating intelligence and the attainment of status: Ethnic aspects in the development of Israel as a certifying society. In A. Yogev (Ed.), Hitpashtut hahaskalah beyisra'el [Educational expansion in Israel] (pp. 
29-53). Tel Aviv: Tel Aviv University and Massada.

Yonah, Y. (2005). Bizkhut hahevdel: Haproyekt harav-tarbuti beyisrael [In virtue of difference: The multicultural project in Israel]. Jerusalem and Tel Aviv: The Van Leer Jerusalem Institute and Hakibbutz Hameuchad.

Yonah, Y., \& Saporta, I. (2002). Hahinukh hakdam-miktso'i viyetsirat ma'amad hapo'alim beyisra'el [Pre-vocational education and the making of the working class in Israel]. In H. Hever, Y. Shenhav, \& P. Motzafi-Haller (Eds.), Mizrahi'im beyisra'el: Iyun bikorti mehudash [Mizrahim in Israel: A critical observation into Israel's ethnicity]. Jerusalem and Tel Aviv: Van Leer Jerusalem Institute and Hakibbutz Hameuchad.

Yonah, Y., Naaman, Y., \& Mahlev, D. (Eds.). (2007). Keshet shel de'ot: Seder yom Mizrahi lahevrah beyisrael [Rainbow of opinions: A Mizrahi agenda for Israel]. Tel Aviv: November Books.

\section{Notes}

Note 1. Similar writing about the cultural experience in Eretz-Israel between Jews and Arabs and between Mizrahi and Ashkenazic Jews can be seen with other Ashkenazic authors from the same era - see, for example, Moshe Smilansky (1874-1953, under the nom de plume Havaja Musa, who wrote Bnei Arav [Children of Arabia]) and Haim Hazaz (1898-1973, who wrote the novels Yaish and Hayoshevet Baganim [Thou that dwellest in the gardens] about the immigrants from Yemen).

Note 2. It should be noted that the literary critics did not heap praise either on the styles of Burla and Shami, who feature Mizrahi Jewish characters in their writings. Barash argued that Burla's style was careless (Barash, n.d.). Fichman (1952, p. 318) argued that "it lacks the tradition of the expression, that its strength lies in discipline, in precision. Its strength is in a primitive, non-thought-out outlook." Dan Miron (1960, pp. 271-272) writes about Burla's writing: "He collects, broods, and is not mature" [Hebrew: oger, doger v'eino boger]. In contrast, Shaked (1988, p. 97) argues that Burla is familar with the Mizrahi world from inside, and tries to take real characters from it. Not only that, but while encountering the foreign world and negotiations with the Arab world, his heroes undergo similar processes to those of Berdyczewski, without describing the "tear in his heart". Yosef Chaim Brenner "punished" Shami, because his writing did not meet his universal criteria, by marking him a local-genre author. The critics who followed him, who, as noted, espoused the same "universal" criteria themselves disguised as alternative expressions, "punished" Shami by positioning him as a "niche author". Asher Barash, who had done much for Shami, including collecting his works had already behaved in the same way. However, Barash was careful to declare at the beginning of the anthology of Shami's stories that his creativity is paltry, but "he is worthy of a place of honor on the shelf of new Hebrew prose". However, at the same time, he labeled him as "one of the first buds of renewed Mizrahi Jewry in Eretz-Israel" (ibid.). When Yitzhak Shami writes Nikmat Ha'avot (1928), literary critic Gershon Shaked (1975, p.5) labels him "a Jewish-Arab author who wrote Hebrew".

Note 3. This criticism is written against the background of the concept of "Orientalism", determined by Edward Said (1953-2003), a Palestinian literary researcher and critic, even though Hakak was not directly influenced by him.

Note 4. It is worth remembering that said by Haim Hazaz, a Western author who, like Churgin, also wrote about Mizrahi characters: "We are walking on the edge of the abyss from the aspect of Levantinism! We must try and bring the European culture to the Edot Hamizrah, we cannot turn into a Mizrahi nation. I am greatly opposed to this. We have traversed a journey of two thousand years to become a European-Jewish cultural unit; we cannot turn back the clock and accept the culture of Yemen, Morocco, Iraq" (Interview with Haim Hazaz, in Shohat, 1971). Hazaz places words like these in the mouth of one of his heroes, Uri, in "Ofek natui" (Hazaz, 1958).

Note 5. It is important to emphasize before the review that each such anthology, published by Churgin, was written around twenty-five years after the previous one. Therefore, the Ashkenazic characters portrayed in Alumot and Yalkut Sipurim and who do not appear in Sipurim, are different from the Mizrahi characters, not only from the ethnic perspective, but also because of changes in the times.

Note 6. It is important to emphasize before the review that each anthology published by Churgin, was written around twenty-five years after the previous one. Therefore, the Ashkenazic characters portrayed in Alumot and Yalkut Sipurim and who do not appear in Sipurim, are different from the Mizrahi characters, not only from the ethnic perspective, but also because of changes over time.

\section{Copyrights}

Copyright for this article is retained by the author(s), with first publication rights granted to the journal.

This is an open-access article distributed under the terms and conditions of the Creative Commons Attribution license which permits unrestricted use, distribution, and reproduction in any medium, provided the original work is properly cited. 